\title{
The Art of Achieving Wholeness: Adult-Learning in Presence and Listening Intercultural Encounter in Healthcare and Counselling before and during Covid-19
}

\author{
Ulrike Elsdörfer \\ Pastoral Psychologist and Cultural Anthropologist \\ North West University, Potchefstroem, South Africa \\ Email: ulrike.elsdoerfer.1@gmx.net
}

\begin{abstract}
:
Counselling in healthcare is a method-based encounter between two persons. This is at least the definition according to psychology. One person, the client, has the chance to express mental, social and physical problems. The other person, the counsellor or therapist, kmakes use of her or his knowledge, intuition and responsiveness, in order to explore and heal. Spiritual counselling follows the same procedure. The counsellor is a trained religious person, aspects of spirituality give a distinct notion to the process. Group therapies relate to the needs of people in indigenous worlds, and non-western thinking as well as post-colonial analysis assists to make visible deep social shifts between different societies in a globalized world. Presence and listening are the two dominant qualities of a therapist, a counsellor or a spiritual advisor in this context. What happens, if exactly these qualities are rejected by needs of healthcare? How are the impacts of a globalized pandemic like COVID-19 on this concept of therapy, counselling and encounter in spiritual dimensions? What will lead to a form of community and social life? How does mental health prevention look like in times of challenges?
\end{abstract}

Article History:

Received: 17 November 2020

Accepted: 29 July 2021

Keywords:

western psychology;

cultural psychology healthcare

in pandemics;

churches;

counselling;

therapy;

post-colonial settings.

\section{Introduction}

When meeting in Accra, Ghana, August 1999, the ICPCC's (International Council on Pastoral Care and Counselling) $6^{\text {th }}$ Congress was opened by the Ghanaian vice president's wife. She was reminding the participants that their outstanding professional role is just to listen. Congresses of ICPCC gather psychologists, religious scientists and religious practitioners from all around the world and from different religions, in order to have an encounter on the art of listening: to each other, to patients in hospitals, to prisoners, to victims of natural disasters or violence, to in many ways challenged people.

Regarding the global political and social developments within the 22 years after the Ghanain lady's speech, her words need to be explained. Post-colonialism brings along 
various sophisticated interpretations of culture(s) and intercultural encounter. How far does psychology and counselling contribute to the debate on post-colonialism? Pandemics have to be added, as HIV AIDS in Southern Africa, as well as ebola within the entire continent.

The Japanese Great Eastern Tsumani including the atomic threat and its long-lasting effects have to be mentioned as a disaster of more recent times. The devastating impact of COVID-19 on Indian Health system came about in 2021. Can presence, personal encounter and listening be of any assistence? What considerations exist for addressing integrity and wholeness of people or patients in need and suffering? What is counsellor's listening? ${ }^{1}$

Counsellors' listening is based on psychological knowledge, which was mainly developped in Europe and in the USA within the 20th century. After wars and political threats, like racial discrimination unto Holocaust, people needed assistance to gain new hope and perspectives in life. They had to flee from homes, had to leave their countries, had to give up their cultural identities and had to build up new social relations. They had to establish a new way of life. This caused troubles and irritations for many of them, and not so few people tended to lose mental balance and trust in life, in their cultural roots or in their religions. Therapies like the Logotherapy of the Austrian Jewish Psychologist Viktor Frankl ${ }^{2}$ assisted to guide through existential crises. Frankl himself had been a prisoner of a German concentration camp, and with his practical resilient experience in situations where power and meaning seemed to diminish, he opened pathways for his clients to cope with hopeless situations, gaining for a viable perspective for a better future.

Before and after Frankl many other psychologists developped their special knowledge, in order to cope mentally with life. Among them are predominantly the therapists Sigmund Freud ${ }^{3}$ and Carl Gustav Jung ${ }^{4}$. Anna Freud ${ }^{5}$ and Melanie Klein ${ }^{6}$ laid psychological foundations to children's mental worlds. Thanks to the basic findings of the two scholars, there is a chance to gain influence on a child's positive development in her or his early lifetime.

The predominant method of the therapist is: to listen what the client tells, what the child expresses, even non-verbally, and then: to work with her/his client by using her/his knowledge. The therapist's emotions and thoughts (when listening) may serve as a mirror of

\footnotetext{
${ }^{1}$ Ulrike Elsdörfer. Spirituality in Diversity: South East Asia meets South Africa Towards a global view of Spiritual Counselling. (Cape Town, South Africa: AOSIS, 2019).

${ }^{2}$ Austrian neurologist and psychiatrist, founder of existential analysis, 1905-1997.

${ }^{3}$ Founder of psychoanalysis, 1856-1939.

${ }^{4}$ Founder of analytical psychology, 1875-1961.

${ }^{5}$ Co-founder of children's psychoanalysis, daughter of Sigmund Freud, 1895-1982.

${ }^{6}$ Co-founder of children's psychoanalysis, 1882-1960.
} 
the client's expresssed words and feelings. Depth psychology speaks oftransference and countertransference. Here the therapist tries to explore the meaning of an interaction. He/she provides informations and explanations. The client may decide whether he/she can accept those explanations. The client may decide whether they will assist her/him in abandoning bad and useless experiences of the past. Her/his personal integrity in terms of mental health may grow. Working on explanations may help to cope with life. Listening is all, giving informations may help, teaching about is of no use in this process. What tended to be the fundament of an upcoming profession in the western world of the 20th century, -being psychologist-, challenged the traditional roles of priests and pastors as counsellors. For a long time in history, the clergy role-model was about teaching and leading souls - sheep and shepherd. This has changed within the last 40 years. Most of the nowadays clergy are trained in the above mentioned therapeutic way of counselling. They define their role as pastoral counsellors in close connection to a psychologist's professional role, though these two professions have a distinct definition of their basic assumptions and aims and their differences. A psychologist works mainly for an improvement of mental health, while a pastoral counsellor wants to accompany a spiritual journey. ${ }^{?}$

With globalization, different approaches to spirituality come into consideration. They sometimes question the legitimacy of psychology in its wish to achieve mental health as the all abundant goal. For instance in grief, a pastoral counsellor can be aware of her/his client's depression. She/he is not predominantly interested in abandoning this sort of mental illness, but she/he prefers to accompany the client through his/her deep valleys of emotions. Pastoral counsellors do not have to evaluate, do not follow a medical standard, they are free to rely on their spiritual values - for instance of regaining hope by following the pathways of their clients" mental and spiritual experiences. This example, describing a slight difference between western psychologists and western pastoral counsellors, may be applied to another difference, coming into conderation with globalization: not all people are of western mentality.

Counselling in the above mentioned Western style is defined as a process between two persons: the client and the counsellor. Developped from the European and North American roots, therapists in Australia/New Zealand/USA, changed settings of approaching their clients, mainly, if their clients were members of a family. The notion was, that people in

\footnotetext{
${ }^{7}$ Aras Bozkurt, et all. "A global outlook to the interruption of education due to COVID-19 Pandemic: Navigating in a time of uncertainty and crisis." Asia Journal of Distance Education, Vol.15, Iss.l (2020): 1-126 (3). https://doi.org/10.5281/zenodo.3878572.
} 
many cultural settings outside the so called western world define their life as members of a clan or an extended family, According to family therapy, the counsellor is confronted with a group of clients. ${ }^{8}$

Sometimes even a group of counsellors is listening to stories and narratives, on which the family's or clan's life is based. Native and family therapy works with an entire community, as long as the members are available for a therapeutic and healing process. ${ }^{9}$ Nevertheless, the predominant work of the counsellors is listening and providing useful interpretations in any case.

\section{Counselling In Post-Colonial Settings}

Globally, various approaches to counselling processes depend on most different needs of societies. At ICPCC's 1lth Congress on Pastoral Care and Counselling in Malacca or Malaysia, 2019, a researcher reports from Samoa:

Counselling in the Samoan context has been a traditional practice...., involving elders who are often also matai (title holders). Such traditional practices involve a more didactic and directive encounter from these community leaders. Over time, and partly influenced by the first Protestant missionaries into Samoa in $1830, \ldots$ these community counselling roles have now become important roles of church ministers and their wives. An emerging ethos of individualism is challenging traditional notions of collectivism in the culture and traditions of Samoa....

This evolution has been identified and described as the "changing Samoan self". This workshop is based on my doctoral research that presented the voices of 34 Samoan participants living in Samoa that included ministers, minister's wives, matai, New-Zealand born Samoans, church members, and service users of a domestic violence agency. Participants shared their expectations of being counselled as well as counselling others, together with reflections concerning effective and ineffective counselling practices.

Va'aalo pastoral counselling (VPC) that conceptualises traditional Samoan canoe fishing using a bonito canoe (va'aalo), came forth from my research. As an approach that incorporates the concept of a changing Samoan self, Va'aalo pastoral counselling (VPC) is framed with the minister and his wife becoming co-counsellors in the process of

\footnotetext{
${ }^{8}$ Aras Bozkurt, Aras, et all. "A global outlook to the interruption of education due to COVID-19 Pandemic: Navigating in a time of uncertainty and crisis": 4-5.

${ }^{9}$ David Epston, co-founder of narrative therapy, 1994-, Michael White, co-founder of narrative therapy, 1948-2008.
} 
counselling. ${ }^{10}$ Further, the minister and wife both encourage a dialogical approach in their pastoral counselling work. Navigating relational space $(v \bar{a})$ is necessary for the many social interactions Samoans are involved, demanding pastoral counselling practices to also consider $v \bar{a}$ in order to become effective and relevant to church members who use this service. ${ }^{11}$

Following the reports from the abovementioned Congress, a researcher from India refers especially to Health Care in India and its needs for counselling:

Chaplaincy department in India in hospital setting is a wonderful ministry. The spiritual needs of the people who come to the hospital for treatment is tremendous, irrespective of their religion. The quest for a divine healer instills in the hearts and minds of those who come for healing to the hospital. India is a multi-cultured and multi-religious country. The people are from different race, ethnicity, social division and language....

I am from Northeast India and left home to go to South India to pursue my studies. It was a different kind of experience where I was exposed to the Other at a close range. The culture, food, physical features and language was entirely diverse. My experience at Christian Medical College and Hospital made me more aware of the need to embrace the Other as our own. The service rendered to people across cultures and religious beliefs is very unique and challenging.

Providing Care and guidance to the suffering community is very essential despite the faith anyone profess. The compassionate touch of the caregiver becomes healing despite the religions one follow. The ministry of presence is emphasized as they render care to people of various religions and cultures. The dynamics in the hospital setting is entirely different. Faith plays an important role in times of pain and sickness. It is the ultimate hope that people turn and hold on to. Chaplain's role in serving people in the healing ministry in India:

1. To enable and equip the churches in India in their healing ministry,

2. To promote fellowship, knowledge and skills in pastoral counseling to hospital chaplains and pastors,

3. To provide theological, spiritual and ethical inputs on issues,

4. To develop vision and goals for Health, Healing and Wholeness.

\footnotetext{
${ }^{10}$ Alesana Pala'amo. "Pastoral Counselling in a Changing Samoa: Development, Christianity and Relationality." A Journal of Social Anthropology and Sultural Studies, Vol.16, No.1 (2019): 95-108. https://doi.org/10.11157/sites-id442.

${ }^{11}$ Alesana F. Pala'amo: Va'aalo Pastoral Counselling: An approach that navigates $v \bar{a}$ (relational space) to engage Samoans with one's own self, with one another, and especially with God. See S.B. Webb. "Assisting in the Development of Counselling Services in a Post-colonial Era: Experiences in Kiribati." International Journal for the Advancement of Counselling, Vol.29 (2007): 137-148. https://doi.org/10.1007/s10447-007-9034-9; Alesana Pala'amo. "Pastoral Counselling in a Changing Samoa: Development, Christianity and Relationality": 95-108.
} 
5. To nurture health professional students in government, private and Christian institutions. $^{12}$

A last report from the Congress in Malacca, Malaysia: African researchers inform about Diakonia and the role of storytelling, art- and music therapy in an African contextualized pastoral care and counselling model:

Since South Africa has become a democratic state under the governance of the African National Congress in 1994, many voices arose that call for the decolonizing of programs presented at universities. This is also true to the pastoral care and counseling modules. Most of the content of these modules were previously written from a Western perspective and has no or little meaning to African students. While looking at the African culture, the authors came to realize the importance of diakonia and the role of story telling, art-and music therapy as channels to facilitate inner healing and dealing with emotional wounds in the pastoral care and counselling process. Diakonia empowers counselees to heal, while facilitating healing to others in their communities. They will present an African contextualized pastoral care and counselling model based on diakonia, storytelling and art-and music therapy. ${ }^{13}$

Addressing integrity and wholeness of people or patients in need and suffering. Samoans are in need of navigating a viable space - for the individual as well as for the interactions of communities. On one hand they are in search of a comfortable manner of living together in a traditional way of life, as families with their hierarchies. On the other hand they want to adapt to modern global lifestyle, giving space to an individual form of life. $^{14}$

Aier refers to the rich religious traditions India has to provide to all citizens, regardless of which type they are. Regarding her profession, she is member of a small religious minority, though this group is quite influential in terms of money, medical experience and equipment. Breed and duPlessis lay their impact on art-and music therapy as a model of creating community between persons in need of mental and physical support in life. In the case of South Africa, sometimes suffering may be inherited from social schisms of the past political times. Storytelling provides a concentration on common experiences, deriving from positive traditions, whether they are rooted in indigenous life or in shared roles

\footnotetext{
${ }^{12}$ Imtimenla Aier, part of the Healing Ministry of the Church. Currently, works as the National Secretary for Chaplains Section of Christian Medical Association of India (CMAI). CMAI is the health arm of National Council of Churches in India. Comp. Ramakrishnan Parameshwaran. "Theory and practice of chaplain's spiritual care process: A psychiatrist's experiences of chaplaincy and conceptualizing trans-personal model of mindfulness." Indian Journal Psychiatry, Vol.57, No.l (2015): 21-29. https://doi.org/10.4103/00195545.148511.

${ }^{13}$ Gert Breed and Dr. Amanda du Plessis, North-West University, South Africa, presenting a workshop at the llth ICPCC Congress in Malacca, Malaysia.

${ }^{14}$ See Byron Malaela Sotiata Seiuli. "Counselling Psychology from a Samoan Perspective." New Zealand Journal of Psychology, Vol.42, No.2, (2013): 42-50.
} 
of overcoming threats and dangers. Storytelling is of assistance for healthcare. But storytelling refers as well to happy and lucky periods of community life in African societies. ${ }^{15}$

\section{Do Pandemics Give Space to Encounter and Presence?}

Up to this point, results are presented on the different manners of approaching mental and physical health problems. Scientifically based methods of crreating a setting for encounter and presence are introduced. The tools were found within the twentieth and the upcoming 2lst century. Since the beginning of 2020, the global approach to healthcare challenges has changed enormously, and the impacts of the COVID-19 pandemia affects counselling activities deeply.

What means learning about an access to humans in a time of felt danger and threat? There seem to be only few good and useful ways of addressing the individual in a personal encounter. There is no real chance of bringing together the community and by that improve its healing resources? How can individuals and communities remain in contact when not being able to meet physically?

The South African Pastoral Psychologist and Theologian Vhumani Magezi is deeply concerned about the current chance of counselors to approach people in need by listening, by encounter and presence. Reflecting the role of the churches, and their counselling work, he fears the loss of a spiritual dimension. The wider South African society seems to abandon spirituality as a source for healing. Everything is about relying on medical and chemical science (which is important at all.) A superficial handling of the partnership between civil society and churches leads to a loss of influence of the churches and their spiritual impacts in creating a social space. The key tools spirituality can contribute to public development, are: counselling, bereavement support, community healing and mobilisation. Everything is based on a narrow contct and fellowship of people. Exactly this is blocked by the lockdown and by the currently felt public opinion about neighbors: "What they touch you should not touch, where they stand you should not stand.“16

A degradation of the quality of community life is a very alarming sign within a society like the South African. Here Ubuntu, the notion of belonging, until now was an eminent part of

\footnotetext{
${ }^{15}$ Ulrike Elsdörfer. Compassion -Kirchen in Afrika: Beratung und soziales Engagement. (Sulzbach/Taunus, Germany: Deutsche Nationalbibliothek, 2011).

${ }^{16}$ Vhumani Magezi: citation from an unpublished paper: Problem statement - Problematic issues raised by COVID-19 for the Church in South Africa; Vhumani Magezi. "Reflection on pastoral care in Africa: Towards discerning emerging pragmatic pastoral ministerial responses." In die Skriflig/In Luce Verbi, Vol.50, No.l: https://doi.org/10.4102/ids.v50il.2130.
} 
the state ideology. Though churches in South Africa are priviledged to provide material goods, such as rooms for patients in need of any private space, the explicit and special quality of providing spirituality currently seems not to be needed. ${ }^{17}$ The spiritual dimension of the pandemic is widely neglected. It seems not to be relevant, compared to scientific and health processes:

A critical observation that can be made about COVID-19 and the church is that the pandemic has impacted the very heart and soul of what it means to be humane and relating....People were prohibited to mingle and mix with others, either for fellowship, worship or any other social gathering. Social distancing, the wearing of masks and sanitisation seemed to communicate the message that a fellow human being is a threat to your health and should be avoided. ${ }^{18}$

Virtual churches do not substitute koinonia. Certainly there is no reason to underestimate the importance of providing hands-on support and a silent place for retreat, which is lacking very often. Regarding Germany (and Europe) in times of pandemics, there are similarities to Magezi's findings about the situation in South Africa. For the entire community of the European countries, there are only a few informations about their inner social constitution during the extraordinary period of 2020/2021. Most of the informations going public are about politics and management of the pandemia. Medical science is broadly involved in giving informations. Talk-shows in TV present everyday life, especially of those people who are engaged in tourism or are owners of restaurants and shops. Artists have to face great challenges; those who are able to chose the internet as a platform, use it. Interpretations of the ongoing change of mentalities will have to wait, maybe they will come out with the elections in September 2021 in Germany.

As parts of the European countries are rich, the governments can provide many social packages. Nevertheless, Diakonia or Caritas and big social organisations like Red Cross contribute with their practical assistance. The often very silent service of providing care and counselling in hospitals, especially to the members of the staff, was accepted, even needed in 2020/21, during the great challenges for healthcare workers. These challenges still do not end. Internet and TV transmitted services of the Catholic and Protestant churches, any other spiritual approach to the public, like teaching or counselling is, and was also before the pandemic, quite rare. Some speakers give a short weekly sermon in TV or a daily intro in a radio broadcast. Only few counsellors give a sort of advice in internet settings, but it is not

\footnotetext{
${ }^{17}$ See Anna Nolte, Charlene Downing. "Ubuntu-the Essence of Caring and Being: A Concept Analysis." Holistic Nursing Practice, Vol.33, No.l (2019): 9-16. https://doi.org/10.1097/HNP.0000000000000302.

${ }^{18}$ Citation from: Problem statement - Problematic issues raised by COVID-19 for the Church in South Africa.
} 
comparable to an interaction in a counselling setting. In general, internet is not yet accepted to be an adequate form of encounter in presence and listening. Germans rely very much on the setting of private and personal meeting, when opening their minds in a confidential manner. ${ }^{19}$

\section{Conclusion: Presence and Listening Before and in Times of COVID-19}

Regarding the long lasting process of developing approaches to the human soul, mind or psyche, the last century and the first 20 years of the current century were quite successful. Exploring the deeper qualities of an interaction of two persons, acknowledging the impact of power in any communication, positive responding as a tool for letting personalities grow all this was a great success for manking and science. Social sciences gave insights in structures of communications, they opened the doors to a more adequate understanding of different cultures. This brought about a new approach to a global encounter, a listening to global experiences, a presence to the other, which meant as well: a new look on myself and on ourselves.

What was found out in complicated processes, will not be lost within two years. But maybe the usefulness of certain tools will be examined during a vivid threat like a pandemic. One will be: Having a new look on the use of implied psychological power, as it comes along with public restrictions. This will be necessary from different sides. It is not only a political task, but it refers to deeper layers of mentalities. Another one: Maybe an old undercurrent schism between science and philosophy, felt and expressed during the current public unimportance of churches and spirituality, may lead to a changed view on philosophy as a key to existential needs. And maybe it will even open a window to a different awareness of spirituality. The strong impact on the demands of healthcare aspects hopefully will end somewhen, and with it fear will diminish. Maybe then it is time to come back to roots of community life, whether they are from historical and indigenous sources or from modern lifestyle, which has many good proposals to share.

Maybe the once coming ease of mental stress will enable people to abandon wrong developments of former lifestyles of the $20^{\text {th }}$ and the beginning the $21^{\text {st }}$ century, which indirectly lead to pandemics. And: maybe the whole experience brings along more global encounter, and by that define newly the role of internet in personal communication. Maybe

\footnotetext{
${ }^{19}$ Ulrike Elsdörfer (ed.). Whispering Hope: An Access to Spiritual Counselling Competencein Asia and Africa. 2017.
} 
there will come up even closer approaches to mental and cultural qualities, which have to be seen as a result of more distinct listening.

\section{Bibliography}

Aier, Imtimenla. Learning to Serve People from Other Cultures-A Call. Workshop at the 1lth Congress of ICPC in Malacca/Malaysia, 2019.

Astuti, Laily Puji. "The Role of Guidance and Counseling Services in Individual Counseling During The Covid-19 Pandemic." International Journal of Applied Guidance and Counseling, Vol.2, No.1 (2021): 25-30. https://doi.org/10.26486/ijagc.v2il.1592.

Bozkurt, Aras, et all. "A global outlook to the interruption of education due to COVID-19 Pandemic: Navigating in a time of uncertainty and crisis." Asia Journal of Distance Education, Vol.15, Iss.l (2020): 1-126. https://doi.org/10.5281/zenodo.3878572.

Breed, Gert \& Plessis, Amanda du. Diakonia and the role of storytelling, art and musictherapy in an African contextualized pastoral care and counselling model. Workshop at the llth ICPCC Congress in Malacca, Malaysia, 2019.

Chao, Si-Yi \& Wilson, Keith B. "Multicultural Competencies of Healthcare Professionals and Disability-Inclusive in Telehealth during the COVID-19 Pandemic." Acta Scientific Medical Sciences, $\quad$ Vol.4, $\quad$ Iss.12 (2020): 124-131. http://doi.org/10.31080/ASMS.2020.04.0806.

Elsdörfer, Ulrike. Compassion -Kirchen in Afrika: Beratung und soziales Engagement. Sulzbach/Taunus, Germany: Deutsche Nationalbibliothek, 2011.

Elsdörfer, Ulrike. Spirituality in Diversity: South East Asia meets South Africa Towards a global view of Spiritual Counselling. Cape Town, South Africa: AOSIS, 2019.

Elsdörfer, Ulrike (ed.). Whispering Hope: An Access to Spiritual Counselling Competencein Asia and Africa. 2017.

Magezi, Vhumani. Problem statement - Problematic issues raised by COVID-19 for the Church in South Africa, 2021.

Magezi, Vhumani. "Reflection on pastoral care in Africa: Towards discerning emerging pragmatic pastoral ministerial responses.“ In die Skriflig/In Luce Verbi, Vol.50, No.l: https://doi.org/10.4102/ids.v50il.2130.

Marcelin, Jasmine R., Siraj, Dawd S., Victor, Robert, Kotadia, Shaila, \& Maldonado, Yvonne A. "The Impact of Unconscious Bias in Healthcare: How to Recognize and Mitigate 
It." The Journal of Infectious Diseases, Vol.220, Iss. Supp.2 (2019): S62-S67. https://doi.org/10.1093/infdis/jiz214.

Nolte, Anna and Downing, Charlene. "Ubuntu-the Essence of Caring and Being: A Concept Analysis." Holistic Nursing Practice, Vol.33, No.1 (2019): 9-16. https://doi.org/10.1097/HNP.0000000000000302.

Pala'amo, Alesana F. Va'aalo Pastoral Counselling: An approach that navigates vāa (relational space) to engage Samoans with one's own self, with one another, and especially with God. Workshop at the llth Congress of ICPC in Malacca/Malaysia, 2019.

Pala'amo, Alesana. "Pastoral Counselling in a Changing Samoa: Development, Christianity and Relationality." A Journal of Social Anthropology and Sultural Studies, Vol.16, No.l (2019): 95-108. https://doi.org/10.11157/sites-id442.

Parameshwaran, Ramakrishnan. "Theory and practice of chaplain's spiritual care process: A psychiatrist's experiences of chaplaincy and conceptualizing trans-personal model of mindfulness." Indian Journal Psychiatry, Vol.57, No.l (2015): 21-29. https://doi.org/10.4103/0019-5545.148511.

Seiuli, Byron Malaela Sotiata. "Counselling Psychology from a Samoan Perspective." New Zealand Journal of Psychology, Vol.42, No.2, (2013): 42-50.

Webb, S.B. "Assisting in the Development of Counselling Services in a Post-colonial Era: Experiences in Kiribati." International Journal for the Advancement of Counselling, Vol.29 (2007): 137-148. https://doi.org/10.1007/s10447-007-9034-9. 